\title{
Metode Hafalan dalam Pembelajaran Naḥwu di Madrasah Diniyah Kyai Mojo, Tembelang, Jombang
}

\author{
Muhammad Hilmi Bahar Rusyadi, Muassomah*
}

Universitas Islam Negeri (UIN) Maulana Malik Ibrahim Malang, Indonesia

\section{Memorization Method in Learning Nạ̣wu at Madrasah Diniyah Kyai Mojo, Tembelang, Jombang}

\section{E-Mail Address}

mas.bahar996@gmail.com

${ }^{*}$ Corresponding Author

\section{Keywords}

Memorization method; students' understanding; learning Arabic nabowu

\begin{abstract}
Many studies that discuss learning methods naḅu, there is no method that can be accurate to be applied to all Madrasahs. Madrasah Diniyah Kyai Mojo, Tembelang, Jombang, is one of the Madrasahs that applies the rote method to improve the quality of understanding nabiwu. The purpose of this study is to find out how the application of memorization methods in Madrasah Diniyah Kyai Mojo, Tembelang, Jombang, in improving the quality of students' understanding of nahwu. This study uses descriptive qualitative, and the instrument for collecting data using direct observation, and unstructured interviews. The results of this study indicate that the application of the memorization method in improving nabuu in the Madrasah Kyai Mojo, Tembelang, Jombang consists of two stages, namely the preparation stage and the implementation and evaluation stages. The study concludes that the memorization method is very helpful in improving the quality of students' understanding of nabwu, even though the level of understanding is still at the level of translating and interpreting and has not yet reached the stage of extrapolating (estimating). his study suggests teachers be creative in using learning methods by paying attention to situations and conditions so that learning is not monotonous by using one method.
\end{abstract}

\section{Pendahuluan}

Naḅwu merupakan aspek penting yang harus dipahami oleh siswa dalam pembelajaran bahasa Arab. Ibn Jinnī mengatakan bahwa naḅwu merupakan pedoman dalam berbahasa Arab, sehingga orang non-Arab pun juga bisa berbicara secara fasih seperti halnya orang Arab asli (Ibn Jinnī, 2006). Ilmu nạ̧wu tidak hanya mempelajari $i^{\prime} r a \bar{b}$ dan problematikanya saja, tetapi juga menyinggung masalahmasalah lain yang penting, seperti kedudukan kata dan kalimat, hubungan intern antarunit yang membentuk sebuah kalimat, dan lain sebagainya. (Fiddaroini, 2012, p. 4). Bahkan, di dalam mukadimah kitab al-'Imriți disebutkan bahwa ilmu nạ̣wu itu wajib dipelajari terlebih dahulu karena kalam Arab tanpa ilmu naḅwu tidak bisa dipahami (al-'Imrițī, 2009). Akan tetapi, dalam 
realitanya pembelajaran naḅwu tidak semudah yang dibayangkan. Oleh karena itu, dibutuhkan sebuah metode yang efektif dalam memahami naḅwu (Dodi, 2013). Mengenai hal ini, A. Mualif (2009) mengatakan bahwa ilmu nạ̣wu termasuk ilmu yang susah dimengerti. Meskipun telah banyak metode pengajaran yang dilakukan oleh guru, tetap saja peserta didik merasa kesulitan dalam mempelajarinya. Hal ini menggambarkan bahwasanya dalam proses pembelajarannya, ilmu naḅwu tidak semudah apa yang dibayangkan oleh kebanyakan orang.

Hal lain yang juga perlu diperhatikan terkait pembelajaran ilmu naḅwu saja adalah metode pembelajaranya, graduasi materi, variasi latihan, evaluasi, dan lain-lain (Hakim, 2013, pp. 24-25). Banyak sekali metode baru yang dicipkan oleh para guru dalam menyampaikan ilmu naḅwu dengan tujuan mempercepat siswa agar bisa memahami ilmu naḅwu. Namun demikian, hal tersebut justru membuat bingung siswa, dan menjadikan ilmu naḅwu sebagai salah satu mata pelajaran yang kurang diminati. Oleh karena itu, perlu digunakan sebuah metode yang cocok, serta langkah-langkah yang sesuai untuk para murid sehingga dapat memudahkan mereka dalam belajar ilmu naḅwu (Syifaurrohmah et al., 2019, p. 837). Metode merupakan salah satu aspek terpenting dalam sebuah pembelajaran, dan penyampaian teori tidak berarti apa pun tanpa menggunakan metode yang tepat (Qomar, 2009:17). Saking pentingnya metode, keberhasilan seorang guru dalam mengajar salah satunya dapat dilihat dari penggunaan metode dalam menyampaikan pelajaran (Harahap, 2018, p. 13). Namun, faktanya banyak kita temui seorang guru yang sangat menguasai pelajaran justru merasa kesulitan dalam menyampaikan materi kepada murid-muridnya.

Kajian tentang metode pembelajaran naḅwu telah banyak dilakukan. Beberapa di antaranya, Ahmad Sehri (2010), "Metode Pengajaran Nahwu dalam Pengajaran Bahasa Arab”. Dalam pengajaran ilmu naḅu, terdapat beberapa metode yang biasa digunakan, yaitu metode analogi (qiyāsiyah), metode induksi (istiqrā'ìyah), metode contoh, dan metode teks utuh. Metode-metode ini memiliki kelebihan dan kekurangan masing-masing. Oleh karena itu, untuk memudahkan siswa memahami ilmu naḅu, dibutuhkan metode pengajaran yang cocok untuk menanggulangi kesulitan mereka, yaitu dengan tidak terpaku pada satu metode tertentu saja. Sebaliknya, harus menggabungkan semua metode sesuai dengan kebutuhan situasi dan kondisi para siswa. Selanjutnya, penelitian oleh Ihin Solihin (2017), "Strategi Pembelajaran Nahwu di Pesantren Ciloa Garut dan AlIhsan Bandung”. Di antara strategi yang digunakan dalam pembelajaran ilmu nabwu di kedua pesantren ini adalah strategi konvensional dan kontekstual. Namun, yang menjadi permasalahan adalah guru belum bisa memotivasi dan mengatasi kesulitan mahasiswa dalam memahami materi, khususnya dalam menghafal sejumlah kaidah-kaidah naḅwu.

Penelitian ini bertujuan untuk mencoba menawarkan sebuah metode hafalan yang bisa membantu para siswa dalam mengatasi problematika di atas. Selain sebagai jalan untuk memperoleh pemahaman terhadap suatu materi pelajaran, menghafal juga mampu meningkatkan budaya membaca di kalangan siswa (Fajarini et al., 2017, p. 14). Hal tersebut sesuai dengan pernyataan Muḥammad 'Ațīyah al-Ibrāshī dalam kitabnya yang berjudul al-Tarbīyah al-Islāmīyah waFalāsifātuhā, bahwa ulama' Islam memberikan perhatian khusus terhadap hafalan dan ingatan. Mereka menganggap bahwa hafalan menjadi perantara terhadap pemikiran, penjelasan, analisis, dan pemahaman komprehensif atas materi yang dihafalkan (al-Ibrāshī, 1969).

Hafalan adalah metode yang digunakan untuk mengingat kembali sesuatu yang pernah dibaca, didengar atau dipelajari secara benar seperti aslinya (Mafrudah,2018, p. 30). Dengan kata lain, menghafal adalah menyimpan data (kejadian, imajinasi, informasi) ke memori otak (Lestari, 2019, p. 
667). Menghafal pada umumnya memadukan dua metode, yaitu menambah hafalan (tạfiz) dan mengulang hafalan (takrir) (Masduki, 2018, p. 23). Dalam penerapan metode ini dibutuhkan keuletan dan kedisiplinan siswa agar hafalan mereka benar-benar masuk dan terserap ke dalam otak atau tersimpan dalam memori jangka panjang individu (Rohmaniyah, 2015, p. 116). Karenanya, dalam proses menghafal ada juga perlu adanya murāja' $a b$, yaitu mengulang kembali atau mengingat apa yang sudah dihafal (Anggraini, 2019, p. 1326). Proses ini wajib dilakukan oleh para siswa agar apa yang telah mereka hafal tidak hilang atau lupa.

Metode hafalan merupakan metode pembelajaran bahasa Arab yang hampir pasti menjadi sebuah program wajib di dunia pendidikan Islam, khususnya di pondok pesantren (Windariyah, 2018, p. 311). Selain untuk mendapatkan pemahaman terhadap suatu materi, metode hafalan secara otomatis juga meningkatkan budaya membaca bagi para siswa atau santri. Karenanya, para guru banyak yang menganjurkan siswanya untuk menghafal materi yang telah disampaikan. Anjuran ini menunjukkan bahwasanya menghafal bukan saja menjadi metode belajar individual, tetapi juga menjadi sebuah metode pembelajaran yang ditetapkan oleh para guru.

Penelitian ini bertujuan untuk mengetahui proses pembelajaran ilmu naḅwu, khususnya di Madrasah Diniyah Kyai Mojo, Tembelang, Jombang. Oleh karena itu, permasalahan yang dirumuskan adalah (1) Bagaimana pembelajaran ilmu naḅwu di Madrasah Diniyah Kyai Mojo, Tembelang, Jombang? (2) Bagaimana implementasi metode hafalan dalam proses pembelajaran ilmu naḅu tersebut? Dari kedua permasalahan ini, asumsinya adalah, ilmu naḅwu merupakan pelajaran yang rumit dan membingungkan. Oleh karena itu, dibutuhkan metode yang mudah dan efektif untuk membantu para siswa dalam memahaminya sehingga mereka tidak lagi merasa kebingungan setelah dijelaskan oleh guru. Metode hafalan sangatlah efektif dalam meningkatkan pembelajaran ilmu naḅwu. Ilmu naḅwu merupakan kadiah yang mendasar dalam mempelajari teks bahasa Arab. Bahkan, umumnya pondok pesantren salaf mewajibkan para santrinya untuk menghafal sebelum mereka mendapatkan pemahaman tentang kaidah-kaidah ilmu naḅwu. Para ulama' salaf berpendapat bahwa dalam mempelajari ilmu naḅwu, hal yang mendasar yang harus dilakukan oleh para siswa atau santri adalah menghafal.

\section{Metode Penelitian}

Penelitian ini merupakan studi lapangan (field research), yaitu sebuah studi penelitian yang mengambil data autentik secara objektif. Sementara itu, untuk jenisnya, penelitian ini termasuk penelitian kualitatif deskriptif, yaitu penelitian yang menghasilkan data deskriptif berupa ucapan atau tulisan dan perilaku orang-orang yang diamati (Sujarweni, 2014, p. 19). Adapun fokus penelitiannya adalah pembelajaran ilmu na b̧wu yang dilakukan oleh para guru (asātìdh) di Madrasah Diniyah Kyai Mojo, Tembelang, Jombang, dengan sumber informan yang terdiri dari pengasuh, dewan asātīdh, lurah atau ketua pondok, dewan pengurus, dan juga para santri kelas alAjurrümiyah.

Data dalam penelitian digali melalui observasi secara langsung dan wawancara tidak terstruktur. Data yang diperoleh dari observasi terkait bagaimana proses pembelajaran ilmu naḅwu, metode yang digunakan oleh asātīdh, dan keaktifan santri. Sementara itu, wawancara dilakukan dengan menggunakan pedoman garis besar permasalahan yang akan ditanyakan. Penelitian diukur dengan kevalidan informasi yang didapat melalui teknik credibility triangulasi sumber. Data dibandingkan dan juga dicek kembali tingkat keakuratan suatu informasi yang diperoleh pada waktu dan juga 
dengan alat yang berbeda. Ada dua cara yang digunakan dalam penelitian ini, yaitu pertama, membandingkan data hasil wawancara dengan data hasil pengamatan yang telah dilakukan. Kedua, membandingkan hasil wawancara dengan isi suatu dokumen yang berkaitan dengan penelitian.

Data yang sudah terkumpul selanjutnya dilakukan analisis berdasarkan analisis kualitatif. Tahapan-tahapan analisis yang dilakukan dalam penelitian ini menggunakan tahapan analisis yang dicetuskan oleh Miles dan Huberman yang meliputi reduksi data (data reduction), penyajian data (data display), serta penarikan kesimpulan dan verifikasi (conclusion drawing / verification). Reduksi data dilakukan dengan memilih dan memilah data yang relevan dengan kajian penelitian dari sekian data telah terkumpul. Untuk penyajian data dilakukan setelah melakukan tahapan penyortiran data, yaitu dengan melakukan display data secara naratif deskriptif. Sementar itu, kesimpulan dan verifikasi dilakukan untuk menarik sebuah kesimpulan dari paparan panjang yang sudah disajikan.

\section{Hasil Penelitian dan Pembahasan}

A. Teknik Metode Hafalan di Madrasah Diniyah Kyai Mojo, Tembelang, Jombang

Madrasah Diniyah Kyai Mojo Tembelang Jombang adalah salah satu madrasah yang mewajibkan para santrinya untuk menghafal kitab-kitab ilmu nạ̣wu sesuai dengan tingkatan kelasnya. Untuk santri baru, kitab yang harus mereka hafal adalah Matan al-Ajurrümīyah, sedangkan untuk tingkat kedua adalah kitab Nazm al-'Imrìți, dan di tingkat ketiga atau tingkat paling tinggi adalah menghafal kitab Alfìyah Ibn Mālik. Karena terbatasnya waktu, peneliti memfokuskan penelitian hanya pada tingkat pertama di mana pada tingkat ini adalah proses dari santri yang tidak paham ilmu nabwu sama sekali menjadi paham. Setelah data dikumpulkan dan dianalisis dengan menggunakan teknik kualitatif deskriptif, menunjukkan bahwa penerapan metode hafalan dalam meningkatkan kualitas pemahaman santri terhadap ilmu naḅwu di Madrasah Diniyah Kyai Mojo, Tembelang, Jombang, ada dua tahapan.

\section{Persiapan}

Dari hasil Observasi yang dikakukan diketahui bahwa santri baru yang notabenenya belum pernah mengenal ilmu naḅu awalnya merasa kesulitan ketika akan menghafal kitab Matan alAjurrümīyah. Karenanya, santri senior membimbing mereka tentang cara menghafal yang mudah, meskipun nantinya setiap santri mempunyai cara sendiri-sendiri dalam proses menghafal. Ini terlihat ketika belajar malam ada beberapa santri senior yang diminta oleh beberapa santri baru untuk hanya sekadar berbagi pengalaman awal proses mereka menghafal. Kemudian, para santri mencari tempat terbaik untuk mereka mulai menghafal. Ada beberapa yang melakukannya di musala, kamar-kamar, dan juga halaman pondok, berbaur dengan para santri yang menghafal kitab 'Imrītī dan Alfíyah.

Dalam tahap persiapan ini setiap tingkatan kelas memiliki target hafalan yang berbeda-beda. Di samping itu juga, para santri dituntut untuk memahami terlebih dahulu apa yang akan dihafal sesuai dengan pelajaran yang telah dijelaskan di dalam kelas sebelumnya. Meski begitu, banyak juga santri yang sudah mencuri start dengan menghafal bab-bab materi yang belum dijelaskan oleh guru atau ustaz. Metode "curi start" seperti ini dilakukan oleh kebanyakan santri untuk mempermudah mereka ketika melakukan setoran hafalan kepada guru ketika selesai menjelaskan bab materi dalam kitab. Dalam tahap persiapan ini juga ada beberapa cara yang dilakukan santri dalam menghafal kitab naḅwu, yaitu, pertama, santri membaca berulang-ulang kali materi yang akan dihafal sambil sesekali 
mereka menutup sedikit demi sedikit kitab yang dihafal sampai dirasa cukup lancar. Kedua, santri biasanya mencari tempat yang menurut mereka nyaman untuk menghafal, misalnya di musala, sudut ruangan, bahkan ada yang di halaman pondok. Ketiga, setelah sudah hafal dengan lancar, santri biasanya mencari partner untuk saling menyimak hasil hafalan yang didapat selama satu hari sebelum disetorkan kepada guru.

\section{Pelaksanaan dan Evaluasi}

Tahap ini adalah inti dari proses penggunaan metode hafalan untuk meningkatkan kualitas pemahaman ilmu naḅwu. Dalam pelaksanaannya para santri menyetorkan hafalan mereka kepada guru. Sebisa mungkin mereka menyetorkan apa yang sudah dihafal selama satu hari, dan jika terjadi kekeliruan secara huruf atau bacaan, maka akan langsung ditegur dan diingatkan oleh guru. Teguran ini dilakukan agar para santri dapat menjaga dari kekeliruan dan tidak merasa bahwa apa yang mereka hafal sudah benar semua.

Proses pelaksanaan metode ini biasa dilakukan setelah pelaksanaan pembelajaran Madrasah Diniyah (Madin). Di Madrasah Diniyah Kyai Mojo, Tembelang, Jombang, Madin dilakukan dua kali dalam satu hari-kecuali hari Jumat dan Lamis malam-yaitu pada sore hari setelah salat asar, dan malam setelah salat isya. Dalam menyetorkan hafalan, santri minimal harus menyetor tiga kali dalam seminggu, dan setiap setoran minimal satu bab atau faṣl. Para santri yang ingin menyetorkan hafalan mereka setelah Madin selesai, biasanya tidak langsung kembali ke kamar. Akan tetapi, mereka mengantre di samping guru sambil menyimak santri lainnya. Jika terjadi kesalahan hafalan, guru akan langsung menegur sambil membenarkan. Namun, setelah dibenarkan oleh guru dan santri masih mengulang kesalahan dalam hafalan, maka guru menyuruh santri tersebut untuk antre kembali ke barisan paling belakang. Ini dilakukan secara bergantian dengan santri yang lain.

Di Madrasah Diniyah Kyai Mojo, Tembelang, Jombang, proses pembelajaran kitab Matan alAjurrümiyah dengan metode menghafal adalah kegiatan wajib yang harus dilalui oleh para santri. Oleh karena itu, kualitas hafalan santri juga sangat memengaruhi kualitas pemahaman santri terhadap materi ilmu nậwu yang dijelaskan di dalam kitab Matan al-Ajurrümīyah. Santri yang hafalanya bagus akan jauh lebih mudah dalam memahami dan mempraktikkan isi kitab Matan alAjurrümiyah, baik ketika diberi pertanyaan atau ketika mempraktikkannya ketika membaca kitab kuning yang lain, dibanding dengan santri yang hafalannya lemah atau bahkan tidak hafal.

Dalam proses pelaksanakan pembelajaran ini hampir tidak pernah terjadi interaksi tanya jawab antara guru dan santri. Ini dilakukan sebagai bentuk kepedulian guru terhadap tingkat pemahaman santri terhadap materi yang dihafal. Namun, hasil observasi yang peneliti lakukan menunjukkan bahwa pemahaman guru terhadap materi yang disetorkan oleh santri dapat dilihat dari kejelian guru ketika membenarkan hafalan santri sekecil apa pun. Meskipun pada praktiknya, guru terlihat tidak terlalu serius dalam menunggu setoran hafalan para santri. Hal ini misalnya terlihat seperti masih seringnya guru bertegur sapa dengan para santri ataupun guru lainnya yang lalu lalang di depan kelas.

Adapun evaluasi dalam metode hafalan ini biasanya dilakukan oleh guru terhadap individu para santri. Untuk evaluasi harian biasanya dilakukan ketika guru mengajar akan menanyakan kepada salah satu santri secara acak. Santri yang tidak bisa menjawab atau lupa akan disuruh berdiri untuk beberapa waktu, bahkan ada yang sampai pembelajaran Madin selesai. Pada tahap ini, semua santri dituntut untuk selalu mengulang-ulang bab yang telah mereka hafal. Sementara itu, untuk ujian semester atau kenaikan tingkat biasanya akan diberikan kelonggaran beberapa hari kepada santri 
untuk melancarkan apa yang sudah mereka hafalkan. Ketika sampai pada hari yang telah ditentukan, evaluasi akan dilakukan oleh guru dengan memanggil satu persatu santri untuk dites secara lisan. Tes lisan ini bertujuan untuk mengetahui apakah santri tersebut layak untuk melanjutkan ke jenjang selanjutnya atau harus mengulang kembali. Itu semua tergantung wewenang guru tersebut.

\section{Pembelajaran Nahwu di Madrasah Diniyah Kyai Mojo, Tembelang, Jombang}

Pengasuh Pondok Pesantren Kyai Mojo, Tembelang, Jombang menyadari betul bahwa untuk memahami dan mempelajari kitab-kitab klasik yang kebanyakan "gundul" (tanpa harakat) bukanlah perkara yang mudah. Dengan demikian, mempelajari ilmu naḅwu sejak dini wajib hukumnya bagi santri baru untuk mempermudah pembelajaran selanjutnya. Sudah bukan rahasia umum lagi bahwa memahami ilmu naḅwu adalah senjata yang paling ampuh dalam memahami "kitab gundul", khususnya bagi orang-orang non-Arab. Oleh karena itu, para santri diwajibkan mempelajari kitabkitab ilmu naḅu, dan khusus bagi santri yang masih baru, kitab yang dianggap paling tepat bagi mereka adalah kitab Matan al-Ajurrümīyah. Kemudian, dalam pemilihan sebuah metode yang tepat untuk dapat membantu santri dalam mempelajari ilmu nạ̣wu, Madrasah Diniyah Kyai Mojo, Tembelang, Jombang, memilih metode hafalan yang diterapkan kepada para santri dalam mempelajari kitab Matan al-Ajurrümīyah. Adapun hasil dari keefektifan metode ini dapat dilihat dari beberapa ungkapan para guru yang mengampu kelas naḅwu dan juga para santri senior atau alumni yang sudah pernah mengalami secara langsung tentang proses dan hasilnya.

Para santri di Madrasah Diniyah Kyai Mojo, Tembelang, Jombang, dapat dengan mudah memahami kitab Matan al-Ajurrümīyah. Ini dibuktikan ketika para santri sudah mulai beranjak ke kelas berikutnya, mereka sudah tidak kesulitan lagi memahami ilmu naḅwu. Ini juga diakui oleh para guru (asātìdh) yang mengampu di kelas berikutnya, baik yang mengampu langsung pelajaran na hwu atau pelajaran lainnya yang berhubungan dengan kitab-kitab klasik. Tentunya, ini sangat memudahkan para guru untuk menyampaikan pelajaran yang mereka jelaskan. Para santri yang dengan sangat seius dalam mengikuti progam hafalan tersebut dapat menjawab pertanyaan dari para guru atau adik kelasnya dengan sangat mudah.

Adapun hasil dari observasi dan juga wawancara yang dilakukan peneliti kepada orang-orang yang terlibat dalam pembelajaran nạ̧wu di Madrasah Diniyah Kyai Mojo, Tembelang, Jombang, menunjukkan bahwa kualitas pemahaman santri terhadap kitab Matan al-Ajjurrümīyah adalah sebagai berikut: pertama, santri bisa menghafal dan juga bisa memahami dan juga menjelaskan isi kandungan dari kitab Matan al-Ajurrümīyah. Kedua, santri bisa mengaplikasikannya dalam pembelajaran Madin, khususnya dalam praktik memahami kitab-kitab klasik atau "gundul". Kemudian, berdasarkan data yang diperoleh peneliti juga menunjukkan bahwa pemahaman santri Madrasah Diniyah Kyai Mojo, Tembelang, Jombang, tentang kitab Matan al-Äjurrümīyah sampai pada tingkat penerjemahan (transliting) dan tingkat penafsiran (interpreting), namun belum sampai pada tingkat membuat estimasi (extrapolating). Di tingkat penerjemahan (translating), santri mampu menerjemahkan bahasa kitab (Arab) kepada bahasa keseharian (bahasa Indonesia atau Jawa) dengan baik dan benar. Sementara itu, di tingkat penafsiran (extrapolating), santri mampu menerapkan atau menyambungkan kaidah nạ̣wu yang dihafal ke dalam kitab-kitab yang lain.

Untuk tingkat penerjemahan, dalam hal ini kualitas kemampuan santri mampu menerjemahkan bahasa kitab ke bahasa sehari-hari, dapat dilihat dari tiga indikator berikut. Pertama, "sangat bagus", apabila kemampuan setoran santri kepada guru yang mengampu pelajaran ilmu naḅwu berjalan 
lancar dan tidak terjadi kesalahan bacaan. Kedua, "bagus", apabila para santri terlihat ragu dalam pelaksanaan setor hafalan kepada guru, namun tidak sampai terjadi kesalahan. Ketiga, "sedang”, apabila santri ketika menyetor hafalan kepada guru, sesekali mendapatkan teguran atas kesalahan bacaan dan hafalan yang kemudian dibenarkan oleh guru. Berdasarkan data-data tersebut, peneliti tidak menemukan kekurangan atau kelemahan santri dalam menerjemahkan kitab Matan alAjurrümīyah. Hal ini disebabkan karena keseriusan santri dalam mempersiapkan hafalan yang akan distorkan kepada guru yang mengampu pelajaran ilmu naḅwu. Sementara itu, untuk tingkatan kualitas santri tentang tiga tingkatan di atas (sangat bagus, bagus, dan sedang), yang membedakannya adalah kualitas kemampuan santri yang berbeda-beda.

\section{Simpulan}

Metode hafalan dalam meningkatkan pemahaman ilmu naḅwu di Madrasah Diniyah Kyai Mojo, Tembelang, Jombang, dapat disimpulakan: pertama, penerapan metode hafalan dalam meningkatkatkan naḅwu di Madrasah Kyai Mojo, Tembelang, Jombang terdiri dari dua tahapan, yaitu tahap persiapan dan tahapan pelaksanaan dan evaluasi. Dalam tahapan persiapan terdapat beberapa teknik, yaitu membaca berulang-ulang, menghafal di tempat yang disukai santri, dan diperdengarkan $(\operatorname{sim} \bar{a})$ kepada temannya sebelum setoran. Sementara itu, dalam evaluasi guru menguji secara lisan kepada santri dan menentukan apakah hafalan santri sudah cukup baik untuk melanjutkan ke jenjang berikutnya. Kedua, metode hafalan sangat membantu dalam meningkatkan kualitas pemahaman ilmu nạ̣wu bagi para santri, meskipun tingkat pemahamannya masih pada tingkat menerjemah (transliting) dan tingkat menafsirkan (interpreting), dan belum sampai pada tahap membuat estimasi (exstrapolating). Namun demikian, penelitian ini memiliki keterbatasan pada satu metode saja untuk meningkatkan kualitas pemahaman ilmu naḅwu santri sehingga belum bisa diukur secara objektif. Karenanya, perlu ada upaya dari para guru untuk menggunakan metode yang paling tepat dan sesuai. Bahkan, guru perlu mengolaborasikan beberapa metode dan tidak monoton pada satu metode saja dalam proses pembelajaran ilmu nạ̣wu yang memungkinkan santri dapat meningkatkan pemahaman mereka. Dengan begitu, santri lebih termotivasi dan bersemangat untuk mengikuti proses pembelajaran ilmu nạ̣wu.

\section{Daftar Rujukan}

Abdurrahman, M. (2014). Penerapan strategi cooperative learning dalam meningkatkan kemampuan nahwu mahasiswa. Jurnal Pendidikan dan Pembelajaran, 21(2), 215-226. Retrieved from http://journal.um.ac.id/index.php/pendidikan-dan-pembelajaran/article/view/7534

Anggraini, D. M. (2019). Metode menghafal Al Qur'an pada anak usia sekolah dasar di SDI Al Munawwarah Pamekasan. Fikrotuna, 10(2), 1320-1337. doi:10.32806/jf.v10i02

Dodi, L. (2013). Metode pengajaran nahwu shorof: Berkaca dari pengalaman pesantren. Tafaqqub: Jurnal Penelitian dan Kajian Keislaman, 1(1), 100-122. Retrieved from http://jurnal.iaibafa.ac.id/index.php/tafaqquh/article/view/7

Fajarini, A., Sutoyo, A., \& Sugiharto, D. Y. P. (2017). Model menghafal pada penghafal Al-Qur'an: Implikasinya pada layanan penguasaan konten dalam bimbingan dan konseling. Jurnal Bimbingan Konseling, 13(19), 13-19. doi:10.15294/jubk.v6i1.17429 
Fiddaroini, S. (2012). Fungsi, guna dan penyalahgunaan ilmu nahwu-sharaf, Madaniya: Jurnal Bahasa dan Sastra Arab, 11(1), 1-15. Retrieved from http://jurnalfahum.uinsby.ac.id/index.php/almadaniyah/article/view/77

Hakim, A. R. (2013). Mempermudah pembelajaran ilmu nahwu pada abad 20. Jurnal Al-Maqayis, 1(1), 1-26. doi:10.18592/jams.v1i1.96

Harahap, A. S. (2018). Metode pendidikan Islam dalam perspektif filsafat pendidikan Islam. Hikmah, 15(1), 13-20. Retrieved from https://jurnalhikmah.staisumateramedan.ac.id/index.php/hikmah/article/view/21

Hermawan, A. (2011). Metodologi pembelajaran bahasa Arab. Bandung: PT. Remaja Rosdakarya. Ibn Jinnī. (2006). al-Khașā'iṣ. (M. 'A. al-Najjār., Tahqiīq). Cairo: Dār al-Kutub al-Mișrīyah.

al-Ibrāshī, M. 'A. (1969). al-Tarbìyah al-Islāmīyah wa-Falāsifatuhā. Beirut: Dār al-Fikr.

al-'Imrīṭi. (2009). al-Durrah al-bahìyah nazm al-Ajurrūmīyah. Giza: Maktabat Awlād al-Shaykh lial-Turāth.

Lail, J., Rohmaniyah, T. L. (2015). Pendampingan hafalan Al-Qur'an dan artinya dengan metode ilustrasi di Dusun Sentono, Klaten, Jawa Tengah. Jurnal Inovasi dan Kewirausabaan, 4(2), 115-118. Retrieved from https://journal.uii.ac.id/ajie/article/view/7909

Lestari, I. (2019). Penerapan metode menghafal (fun teory) dan problematikanya dalam pembelajaran Al-Qur'an Hadits di MTs Negeri 1 Langsa. Al-Ikhtibar:Jurnal Ilmu Pendidikan, 6(2), 663-674. doi:10.32505/ikhtibar.v6i2.607

Mafrudah. (2018). Peningkatan kemampuan hafalan materi Al-Qur'an Hadits melalui metode Index Card Match pada siswa kelas VII-F MTs Negeri I Bantul. Jurnal Pendidikan Madrasah, 3(1), 27-39. doi:10.14421/jpm.2018.31-03

Masduki, Y. (2018). Implikasi psikologis bagi penghafal Al-Qur'an. Medina-Te:Jurnal Studi Islam, 18(1), 18-35. doi:10.19109/medinate.v14i1.2362

Muallif, A. (2019). Metode pembelajaran ilmu nahwu dalam pendidikan bahasa Arab. Al-Hikmah: Jurnal Pendidikan dan Pendidikan Agama Islam, 1(1), 26-36. Retrieved from https://ejournal.uniks.ac.id/index.php/Alhikmah/article/view/60

Qomar, M. (2009). Pesantren: Dari transformasi metodologi menuju demokratisasi institusi. Jakarta: Erlangga.

Sehri, A. (2010). Metode pengajaran nahwu dalam pengajaran bahasa Arab. Hunafa:Jurnal Studia Islamika, 7(1), 47-60. doi:10.24239/jsi.v7i1.108.47-60

Solihin, I. (2017). Strategi pembelajaran nahwu di Pesantren Ciloa Garut dan Al-Ihsan Bandung. AlTsaqofa: Jurnal Ilmiah Peradaban Islam, 14(2), 359-372. doi:10.15575/al-tsaqafa.v14i2.2004

Sujarweni, V. W. (2014). Metodologi penelitian. Yogyakarta: Pustaka Baru Press.

Syifaurrohmah, A., Mahardika, N. W., Mia, N., \& Z, I. F. (2019). Pembelajaran dasar ilmu nahwu dan shorof dengan media cakram pada pemula guna optimalisasi bilingual area. In Kreativitas dan inovasi dalam pembelajaran bahasa Arab di Indonesia. Prosiding Konfererensi Nasional Bahasa Arab V (pp. 836-848) Malang, Indonesia.

Windariyah, D. S. (2018). Kebertahanan metode hafalan dalam pembelajaran bahasa Arab. Ta lim: Jurnal Studi Pendidikan Islam, 1(2), 309-324. doi:10.29062/ta'lim.v1i2.954 